\title{
The Market Quality to Technical Analysis Performance: Intercountry Analysis
}

\author{
Jogiyanto Hartono and Dedhy Sulistiawan ${ }^{\mathrm{b}}$ \\ ${ }^{2}$ Faculty of Economics and Business, Universitas Gadjah Mada, Indonesia \\ ${ }^{b}$ Faculty of Business and Economics, Universitas Surabaya, Indoneasia
}

\begin{abstract}
The main objective of this research is to discuss the impact of market quality on technical analysis profitability using inter-country analysis. Market quality is proxied by market capitalization. Technical analysis performance (profitability) is calculated using technical analysis return for MA5 indicator and short transaction strategy. This study uses the OSIRIS and Yahoo Finance databases. Using 21 countries with 50 companies for each country, this study finds that market quality affects technical analysis performance. Robustness tests are conducted for longer moving average indicators that are MA10 and MA15. To make sure that the results are not sensitive toward the strategy used, other robustness tests are conducted by using short and long-short transaction strategies. All robustness tests confirm the findings.
\end{abstract}

Abstrak: Tujuan utama dari penelitian ini adalah untuk membahas dampak dari kualitas pasar bursa saham terhadap profitabilitas analisis teknis dengan menggunakan analisis pasar saham antarnegara. Kualitas pasar diproksikan dengan kapitalisasi pasar. Kinerja analisis teknikal (profitabilitas) dihitung dengan menggunakan analisis teknis berpatokan pada perdagangan forex indikator MA5 dan strategi transaksi pendek. Penelitian ini menggunakan database OSIRIS dan Yahoo Finance yang berasal dari 21 negara dengan jumlah total 50 perusahaan untuk masing-masing negara. Hasil penelitian menunjukan bahwa kualitas pasar mempengaruhi kinerja analisis teknikal. Tes ketahanan dilakukan untuk melihat lama bergerak indikator rata-rata dari rata-rata perpindahan 10 (MA10) sampai MA15. Untuk memastikan bahwa hasil penelitian ini tidak sensitif terhadap strategi yang digunakan, tes ketahanan lainnya dilakukan dengan menggunakan strategi transaksi pendek serta gabungan strategi panjang dan pendek. Semua tes ketahanan yang dilakukan mengkonfirmasi temuan di atas.

Keywords: long strategy; market quality; moving average; short strategy; technical analysis performance

JEL classification: $\mathrm{G} 10 ; \mathrm{G} 30$ 


\section{Introduction}

The main objective of this research is to examine the impact of market quality on technical analysis profitability using intercountry analysis. This issue is very important to bridge technical analysis studies, because previous studies have produced different results between developing countries and developed countries. Technical analysis signals in developed markets, such as in the United States (U.S.) and the United Kingdom (UK), produce lower performances than those in developing markets such as countries in South America (McKenzie 2007), Eastern Europe (Fifield et al. 2005), and Asia (Ahmed et al. 2000). Those results suggest that market quality of a country affects its technical analysis performance, but none of the studies directly examines this idea.

Previous studies only compared technical analysis returns of each country with U.S. stock returns. Most Asian markets produce better returns than returns in the US market. They use the US market as a benchmark (Bessembinder and Chan 1995). Technical analysis returns in the Greece market are more dominant than those in the US market (Milionis and Papanagiotou 2008). Another study divides stock marketquality based on large and small categories with a nominal scale and only uses European stock markets (Fifield et al. 2005).

This study expands previous studies by (1) expanding the idea using international data, and (2) upgrading market quality proxy from nominal scale to ratio scale as an important determinant for technical analysis returns.

In their seminal article, Jensen and Meckling (1976) describe how ownership proportion will affect managers' behavior. The proportion of ownership itself is also influenced by law and investor protection in a country (La Porta et al. 1998)

When the protective laws for outside investors are enforced, outside investors will tend to fund the company, and ownership becomes more valuable and more dispersed. Conversely, when the law does not protect the interests of investors, the growth of capital markets is not fast (La Porta et al. 2002) and the firms' ownership becomes more concentrated (La Porta et al. 1998). As a result, companies' financial statements in countries with poor enforcement and high ownership concentration are considered less reliable than those in the countries with high enforcement and low ownership concentration. Consequently, information outside the financial statements are needed. One of these is technical analysis signals information. In low markets quality countries, markets are less efficient than that in high quality countries. It means that technical analysis performance will be more (less) useful in countries with low (high) stock market quality.

This paper is organized as follows. Section 2 presents a literature review. Section 3 discusses the research methodology. Empirical results and analysis are presented in Section 4 . In the final section, this study states its conclusions.

\section{Literature Review and Hypothesis Development}

Technical analysis is an investment strategy that uses charts to study stock price movements. Fama and Blume's (1966) study is the most widely cited article in this area. They conclude that technical analysis is not profitable when considering fees. Sweeney (1988) re-examines the methodology used by 
Fama and Blume (1966). The results provide support for the use of technical analysis. Sweeney (1988), Brock, Lakonishok, and LeBaron's (1992) studies use the method of variable-length moving average (VMA) and fixed-length moving average (FMA), and the trading range break-out (TRB). Their results support the use of technical analysis.

According to Shleifer and Vishny (1997), the main reason for stock investors providing external funding is to obtain voting rights. In countries with weaker legal systems, minority shareholder voting rights are not respected. This condition will discourage them from holding stocks for long periods. In countries with good protection, minority investors tend to be willing to conduct longterm investment due to a legal certainty that is sufficient to get the dividend and principal value of their investment. Conversely, in low protection countries, minority investors have no incentive to keep stock for long periods. Those conditions stimulate different investment strategies. In good investor protection countries, stock prices and dividends are higher than those in bad investor protection countries (La Porta et al. 2000a and 2000b) because long-term investment will maintain the price of stocks at a higher level. Conversely, short-term investing strategy will produce bigger volatility.

Technical analysis is used for short-term investments. It means that investors do not intend to invest in long-term horizon. Based on that condition, short-term investments analysis will be used by many investors. When many investors make long term investments, the price will be relatively higher. This was shown by La Porta et al. (2002). Previous studies also indicate that the technical analysis signal is reliable in developing markets, but not in developed markets (Fifield et al. 2005 and McKenzie 2007).
Bessembinder and Chan (1995) examine the performance of VMA, FMA and TRB in the markets of Japanese, Hong Kong, South Korea, Malaysia, Thailand and Taiwan, as well as the market in the United States (U.S.) as a benchmark. In all those countries, except the U.S., technical analysis produces good performances. Ahmed et al. (2000) also examine developing markets with high volatility and a declining trend. The results show that the performances of technical analysis are better than those of buy and hold strategy, except on the U.S. stock market. The study of McKenzie (2007) also uses VMA, FMA and TRB methods. He shows that performances of technical analysis in developing countries are better than those in developed countries. In European markets, the research by Fifield et al. (2005) also reaches the same conclusions. Smaller European markets provide benefits to users of technical analysis, but technical analysis signals are not useful for the larger European markets.

In Indonesia, Sulistiawan and Hartono (2014) give evidence that technical analysis signals before earnings announcements produce profit. In that situation, technical analysis signals capture price reaction before earnings announcements. Conversely, technical analysis signals after earnings announcements do not produce profit because stock prices are not stimulated by new information. That study gives evidence about the conditions affecting technical analysis return. In short, using Indonesian market data they show that technical analysis signals around earnings announcements are useful.

Good investor protection will improve the quality of a stock exchange (La Porta et al. 2000b). If good (bad) investor protection increases (decreases) market quality, then the good (bad) investor protection environment will have an impact on the performances of 
technical analysis. Technical analysis indicators produce good (bad) performances in low (high) quality stock markets as reported by McKenzie (2007); Fifield et al. (2005); Ahmed et al. (2000); Bessembinder and Chan (1995); Millionis and Papanagiotou (2008). Based on the above discussions, this study hypothesizes that stock market quality negatively affects technical analysis performance.

\section{Data}

Data for this study are taken from Osiris and Yahoo Finance databases. Sample consists of firms in countries listed in the OSIRIS database. Lara et al. (2006) show that the OSIRIS database tends to provide bigger companies in a certain country. This study uses market returns of 21 countries that have to be available in both of Yahoo Finance and OSIRIS. Stock price data are collected from Yahoo Finance database. These data are needed to calculate technical analysis returns based on technical analysis signals.

This study observes companies around the world in 2010 and 2011. The main interest of this study is year 2011, because in that year, world stock markets returns declined. Conversely, in 2010, the world stock markets returns tended to rise. By using the different market conditions in these two years, this study covers both bearish and bullish markets. Another reason why this study only uses two years' data is because each year has to be observed with a lot of technical analysis signals for 21 countries with three supportive methods namely MA5, MA10, and MA15. Number of technical analysis signals obtained from MA5, MA10, MA15 are 2,598; 1,690; 1,262 respectively for long strategy. For short strategy, the number of technical analysis signals obtained from SMA5, SMA10, SMA15 are 2,$592 ; 1,674 ; 1,224$ respectively. Therefore, the total number of technical analysis signals used in this research are 11,040 signals.

\section{Empirical Models}

This study employs the regression model to test the hypothesis. This study uses country level in the measurement where subscript $i$ represents the country, and $t$ represents the year. The regression model is as follows.

$$
\begin{aligned}
\operatorname{TAP}_{\mathrm{i}, \mathrm{t}}= & \mathrm{a}+\mathrm{b} 1 \cdot \mathrm{MQUAL}_{\mathrm{i}, \mathrm{t}}+ \\
& \mathrm{b} 2 \cdot \mathrm{YEFFECT}_{\mathrm{i}, \mathrm{t}}+\mathrm{e}_{\mathrm{i}, \mathrm{t}} \ldots \ldots
\end{aligned}
$$

$$
\begin{aligned}
& \operatorname{AdjtTAP}_{\mathrm{i}, \mathrm{t}}=\mathrm{a}+\mathrm{b} 1 \cdot \mathrm{MQUAL}_{\mathrm{i}, \mathrm{t}}+ \\
& \text { b2.YEFFECT } \mathrm{Y}_{\mathrm{i}, \mathrm{t}}+\mathrm{e} 1_{\mathrm{i}, \mathrm{t}} \text {. }
\end{aligned}
$$

$T A P_{i, t}$ is a technical analysis performance; $\operatorname{Adjt} \operatorname{TAP}_{i, t}$ is a technical analysis performance after adjusted by buy and hold return for each country- $i$ for each period- $t, M Q U A L_{i, t}$ is the market quality for each country- $i$ for each period- $t$, YEFFECT $T_{i, t}$ is a dummy variable to control for year effects.

\section{Operational Definition of Variables}

Variables that are used in the regression model are measured as follows.

$\operatorname{AdjtTAP}$ is a technical analysis performance $\left(\mathrm{TAP}_{\mathrm{i}, \mathrm{t}}\right)$ after adjusted by buy and hold return for each country for each period. Technical analysis performance (profitability) is determined by the return of technical analysis signals. Technical analysis is presented in Yahoo Finance and Bloomberg as well as various online stock trading monitors. In long strategy, technical analysis signal return for each stock- $k$, for each country- $i$, and for period- $t$ is calculated from the difference between price on sell signal $\left(\mathrm{P}_{\mathrm{k}, \mathrm{s}, \mathrm{i}}\right)$ and price on buy signal $\left(\mathrm{P}_{\mathrm{k}, \mathrm{b}, \mathrm{i}}\right)$. 


$$
\begin{aligned}
& \mathrm{R}_{\text {sell-buy,k,i,t }}=\left(\mathrm{P}_{\mathrm{k}, \mathrm{s}, \mathrm{I}}-\mathrm{P}_{\mathrm{k}, \mathrm{b}, \mathrm{c}}\right) / \mathrm{P}_{\mathrm{k}, \mathrm{b}, \mathrm{i}} \\
& \text { TAP }_{\text {sell-buy,i,t }}=\Sigma_{\text {Rsell-buy,k, }, \mathrm{i}, \mathrm{t}} \ldots \ldots \ldots \ldots \ldots \ldots \ldots \ldots \ldots
\end{aligned}
$$

Where $T A P_{\text {sell-buy,j,t }}$ is cumulative returns generated from a buy signal that is followed by a sell signal for market index in a country- $i$. Using return of buy and hold, this study adjust the value of $T A P_{\text {sell-buy, }, 3, t}$ Return of buy and hold strategy $\left(\mathrm{R}_{\mathrm{bh}, \mathrm{i},}\right)$ and $\operatorname{adj} T A P_{i, t}$ are calculated as follows.

$$
\begin{aligned}
& \mathrm{R}_{\text {bh,i,t }}=\left(\mathrm{P}_{\text {end,c }}-\mathrm{P}_{\text {begin, } \mathrm{i}}\right) / \mathrm{P}_{\text {begin,i }, \ldots \ldots \ldots \ldots . . .}(4) \\
& \text { AdjtTAPi,t }=\text { TAP } \\
& \text { sell-buy,it }
\end{aligned}
$$

Return of buy and hold strategy $\left(\mathrm{R}_{\mathrm{bhi,t}}\right)$ is calculated by the difference of ending holding price (price of the last sell signal for the period) from the beginning holding price (price of the first buy signal for the period) divided by the beginning holding price. $\operatorname{Adj} A P_{i, t}$ is actually a net return between technical analysis return after adjusted by buy and hold return and calculated by deducting $T A P_{\text {sell-buy, }, \text { t. }}$ with $R_{b b, i, t .}$

In technical analysis, price on sell signal and price of buy signal for each technical analysis signal can be determined using various methods. In many references of technical analysis, for example, Luca (2000) and technical analysis software such as Meta Stock or Chart Nexus, provide many technical analysis indicators that can be used to generate a buy or sell signal. This study uses the Moving Average (MA) that produced good performance in previous researches [Milionis and Papanagiotou 2008; McKenzie 2007; Fifield Fifield et al. 2005; Wonget al. 2003; Ahmed et al. 2000; Bessembinder and Chan 1995; and Brock et al. 1992).

In addition, Moving Average (MA) information is also available on Yahoo Finance as well as in technical analysis softwares. The MA method used is the same with VMA (Variable-length MA), which means the time scale/the time period between buy and sell signals varies. The formula is presented as follow.

$$
\mathrm{MA}_{\mathrm{i}, \mathrm{n}}=\left(\mathrm{P}_{\mathrm{i}, \mathrm{n}}+\mathrm{P}_{\mathrm{i}, \mathrm{n}-1}+\ldots+\mathrm{P}_{\mathrm{i}, 1}\right) / \mathrm{n}
$$

$P n$ is the price $\mathrm{n}$ days ago for country $i$. $P_{1}$ is the price of 1 day ago for country $i$.This study uses three indicators: $M A 5, M A 10$, and $M A 15$. The symbol $\mathrm{n}$ is the period used in this study using the indicator, where $\mathrm{n}$ is 5,10 , and 15 for $M A 5, M A 10$, and $M A 15$, respectively. Buy signal occurs when the stock price the day $0\left(\mathrm{P}_{0}\right)$ crosses up $M A$ line, where $P_{0}>$ $M A$ and $P_{-1}<M A_{-1}$. Sell signal occurs when the stock price on day $0\left(\mathrm{P}_{0}\right)$ crosses down $M A$ line, where $P_{0}<M A n$ and $P_{-1}>M A_{-1}$. The symbol of -1 represents one-day before technical analysis signals.

MQUAL $L_{i, t}$ is the market quality for 50 companies for each country- $i$ for each period$t$. Measurement of market quality is proxied by the average of market capitalization of stocks in the sample in each country. A study by Fifield Fifield et al. (2005) classifies the European market using categorical scale. This study uses not only European countries, but also uses broader data, i.e international data. To improve the quality of data, this study does not only use categorical data, but uses ratio scale to measure market capitalization. Market capitalization is measured with its natural logarithm value.

YEFFECT $T_{i,}$ is a dummy variable to control year effects, with value 0 for year 2010 and a value of 1 for year 2011. The main interest of this study is year 2011, because in that year, world stock markets returns decline. Conversely, in 2010, the world stock markets returns tend to rise. 
This study believes that the regression coefficients vary between years. This study expects that market quality negatively affects technical analysis performance. The hypothesis is accepted if b1 coefficient significantly negative.

\section{Robustness Tests}

To make the results robust, some efforts are conducted as follows.

1. This study does not use one stock trading strategy only. In addition to using MA5, this study also uses $M A 10$, and $M A 15$ to test whether shorter or longer days have different effects.

2. For the technical analysis strategy, this study not only employs long strategy, but also short strategy, and the combination between long and short strategy.

a. For long strategy, technical analysis buy signal is recognized first followed by sell signal.

b. Short strategy is the reverse where technical analysis sell signal is recognized first followed by buy signal. Short strategy is conducted for short selling, where investor sells a stock shortly and then buys the stock when the price falls.

c. For long and short strategy, return is calculated from the combination of short and long strategies. Price determination is becoming the reference return that is the daily closing price at the time the signal has emerged. At the end of the measurement period, the last closing price is used as a reference for the calculation of the last return.

\section{Results}

Market capitalization is a proxy for stock market quality. The market capitalization for each country is shown in Table 1.

Table 1 shows that companies in US and UK markets dominate the value of market capitalization. According to this measure, Greece, New Zealand, and Argentina are examples of stock markets with low market capitalization.

The hypothesis predicts that stock market quality negatively affects technical analysis performance. Market quality (MQUAL) proxies market capitalization. Results of the regression are presented in Table 2 . The residuals of those regressions are normally distributed and no autocorrelation problems are found.

According to the Table 2, long strategies using all indicators show that coefficients for market capitalization negatively affect technical analysis returns. The MQUAL coefficients for $M A 5, M A 10$, and $M A 15$ are 0.023 (t-value is -1.689 significant at $5 \%$ ), 0.031 ( $\mathrm{t}$-value is -2.644 significant at $1 \%$ ), and -0.019 ( $\mathrm{t}$-value is -1.343 significant at $10 \%$ ), respectively.

Robustness tests are conducted using short and long-short strategies in Table 3. In short strategy, market capitalization negatively affects technical analysis return, but only two indicators are significant. Those are $M A 5$ and $M A 15$. The MQUAL coefficients for $M A 5, M A 10$, and $M A 15$ are -0.061 (tvalue is -2.019 significant at $5 \%),-0.061(\mathrm{t}-$ value is -2.140 significant at $5 \%$ ), and -0.043 ( $t$-value is -1.530 significant at $10 \%$ ), respectively. 
Table 1. The Market Capitalization

\begin{tabular}{|c|c|c|c|c|}
\hline Countries & $\begin{array}{c}2010 \text { Market } \\
\text { Capitalization } \\
\text { (in thousand USD) }\end{array}$ & $\begin{array}{l}\text { Observed } \\
\text { companies }\end{array}$ & $\begin{array}{c}2011 \text { Market } \\
\text { Capitalization } \\
\text { (in thousand USD) }\end{array}$ & $\begin{array}{c}\text { Observed } \\
\text { companies* }\end{array}$ \\
\hline US & $112,747,845$ & 50 & $114,715,238$ & 50 \\
\hline UK & $42,591,569$ & 50 & $38,721,103$ & 49 \\
\hline French & $28,206,692$ & 50 & $22,985,906$ & 50 \\
\hline Canada & $23,839,100$ & 50 & $21,055,622$ & 50 \\
\hline Switzerland & $21,661,982$ & 50 & $19,693,146$ & 50 \\
\hline Germany & $22,409,514$ & 50 & $18,644,114$ & 50 \\
\hline Australia & $15,911,122$ & 50 & $17,971,255$ & 50 \\
\hline Hongkong & $17,798,715$ & 50 & $15,961,976$ & 50 \\
\hline Brazil & $14,417,429$ & 50 & $11,742,086$ & 50 \\
\hline Taiwan & $10,406,392$ & 50 & $8,381,196$ & 50 \\
\hline Netherland & $9,161,535$ & 50 & $6,636,688$ & 49 \\
\hline Mexico & $7,023,821$ & 50 & $6,194,825$ & 50 \\
\hline Singapore & $6,886,206$ & 50 & $5,985,064$ & 50 \\
\hline Indonesia & $5,849,843$ & 50 & $5,948,256$ & 50 \\
\hline Malaysia & $4,736,552$ & 50 & $4,996,724$ & 49 \\
\hline Belgia & $4,701,763$ & 50 & $4,162,250$ & 48 \\
\hline Israel & $3,590,511$ & 50 & $2,590,113$ & 49 \\
\hline Austria & $2,363,128$ & 50 & $1,728,619$ & 49 \\
\hline Argentina & $1,005,446$ & 50 & 969,421 & 49 \\
\hline New Zealand & 600,713 & 50 & 772,125 & 49 \\
\hline Greece & $1,200,317$ & 50 & 609,767 & 48 \\
\hline
\end{tabular}

*Several data of companies in 2010 are not available in 2011. 
Table 2. The Impact of Market Quality (Capitalization) to Technical Analysis Performance

Dependent Variable: TAP

\section{Long Strategy}

\begin{tabular}{lccclccc}
\cline { 2 - 4 } & M 5 & M 10 & M 15 & n=42 & M A 5 & MA10 & M A15 \\
Intercept & 0.309 & 0.467 & 0.316 & YEFFECT & 0.148 & 0.068 & 0.025 \\
Stat.t & 1.430 & 2.471 & 1.387 & Stat.t & 4.278 & 2.243 & 0.690 \\
Sig. & $*$ & $* * *$ & $*$ & Sig. & $* * *$ & $* * *$ & - \\
MQUAL & -0.023 & -0.031 & -0.019 & Durbin-watson & 1.701 & 1.759 & 1.805 \\
Stat.t & -1.689 & -2.644 & -1.343 & & & & \\
Sig. & $* *$ & $* * *$ & $*$ & & & &
\end{tabular}

Notes: ${ }^{* * *}$,**, and ${ }^{*}$ denote significance at the 1 percent, 5 percent, and 10 percent levels, respectively (one-tailed test). TAP is technical analysis performance. MQUALis market quality. That is represented by the average of market capitalization of companies in sample countries. YEFFECT $=1$ when year is 2011, and 0 otherwise. Residuals are normally distributed.

Table 3. The Impact of Market Quality (Capitalization) to Technical Analysis Performance: Robustness Tests

Dependent Variable: TAP

\begin{tabular}{|c|c|c|c|c|c|c|}
\hline \multirow[b]{2}{*}{$\mathrm{n}=42$} & \multicolumn{3}{|c|}{ Short Strategy } & \multicolumn{3}{|c|}{ Long-Short Strategy } \\
\hline & MA5 & MA10 & MA15 & MA5 & MA10 & MA15 \\
\hline Intercept & 0.832 & 0.842 & 0.545 & 0.904 & 1.071 & 0.623 \\
\hline Stat.t & 1.727 & 1.830 & 1.213 & 2.014 & 2.862 & 1.591 \\
\hline Sig. & $* *$ & $* *$ & - & $* *$ & $* * *$ & $*$ \\
\hline MQUAL & -0.061 & -0.061 & -0.043 & -0.063 & -0.072 & -0.042 \\
\hline Stat.t & -2.019 & -2.140 & -1.530 & -2.256 & -3.094 & -1.702 \\
\hline Sig. & $* *$ & $* *$ & $*$ & $* *$ & $* * *$ & $* *$ \\
\hline YEFFECT & 0.372 & 0.344 & 0.343 & .285 & .177 & 0.134 \\
\hline Stat.t & 4.826 & 4.676 & 4.784 & 3.974 & 2.960 & 2.137 \\
\hline Sig. & $* * *$ & $* * * *$ & $* * *$ & $* * *$ & $* * *$ & $* *$ \\
\hline Durbin-watson & 1.565 & 1.724 & 1.576 & 1.584 & 1.712 & 1.486 \\
\hline
\end{tabular}

Notes: $\quad * * *, * *$, and $*$ denote significance at the 1 percent, 5 percent, and 10 percent levels, respectively (one-tailed test). TAP is technical analysis performance. MQUAL is market quality. That is represented by the average of market capitalization of companies in sample countries. YEFFECT $=1$ when year is 2011, and 0 otherwise. Residuals are normally distributed. 
In long-short strategy, market capitalization negatively affects technical analysis return, but only one indicator that is significant. It is $M A 15$. The MQUAL coefficients for $M A 5, M A 10$, and $M A 15$ are -0.063 (tvalue is -2.356 significant at $5 \%),-0.072(\mathrm{t}-$ value is -3.094 significant at $1 \%$ ), and -0.042 (t-value is -1.702 significant at $5 \%$ ), respectively. As a control variable, YEFFECT is used to control the year effect. YEFFECT coefficients are significant for all indicators and strategies.

Using technical analysis return data 2010 and 2011, a robustness test was also conducted to calculates technical analysis returns after adjusted by buy and hold returns. That variable is used as dependent variable. The independent variable is MQUAL. The results are presented in Table 4.

According to the results on Table 4, the MQUAL coefficients are statistically signifi- cant for all strategies and indicators, except in short strategy using $M A 15$ indicator. In long strategy, the MQUAL coefficients for $M A 5$, $M A 10$, and MA15 are -0.046 ( $\mathrm{t}-\mathrm{v}$ alue is 1.694 significant at $10 \%),-0.060$ (t-value is 2.743 significant at $1 \%$ ), and -0.032 (t-value is -1.388 significant at $10 \%$ ), respectively. In long strategy, the MQUAL coefficients are 0.118 ( $\mathrm{t}$-value is -1.814 significant at $5 \%$ ) for $M A 5,-0.117$ (t-value is -1.706 significant at $10 \%$ ) for $M A 10$, and -0.069 (t-value is -1.183 insignificant) for $M A 15$.

In long-short strategy, market capitalization also negatively significant affects technical analysis return after buy and hold. The MQUAL coefficients for $M A 5, M A 10$, and MA15 are -0.132 (t-value is -2.249 significant at $5 \%),-0.144$ ( $t$-value is -2.644 significant at $1 \%$ ), and -0.069 ( $\mathrm{t}$-value is -1.429 significant at $10 \%)$, respectively.

Table 4. The Impact of Market Quality on Two-years Technical Analysis Returns After being Adjusted by Buy and Hold Returns

\begin{tabular}{lcccccccccc}
\hline \multicolumn{1}{l}{ Dependent variable: AdjTAP } \\
\hline $\mathrm{n}=21$ & \multicolumn{2}{c}{ Long Strategy } & \multicolumn{2}{c}{ Short Strategy } & \multicolumn{2}{c}{ Long-Short Strategy } \\
\cline { 2 - 11 } & MA5 & MA10 & MA15 & MA5 & MA10 & MA15 & MA5 & MA10 & MA15 \\
\cline { 2 - 11 } & 0.779 & 0.963 & 0.549 & 1.987 & 1.930 & 1.157 & 2.194 & 2.321 & 1.134 \\
Intercept & 1.793 & 2.777 & 1.509 & 1.915 & 1.771 & 1.244 & 2.339 & 2.667 & 1.478 \\
Stat.t & $* *$ & $* * *$ & $*$ & $* *$ & $* *$ & - & $* *$ & $* * *$ & $*$ \\
Sig. & -0.046 & -0.060 & -0.032 & -0.118 & -0.117 & -0.069 & -0.132 & -0.144 & -0.069 \\
MQUAL & -1.694 & -2.743 & -1.388 & -1.814 & -1.706 & -1.183 & -2.249 & -2.644 & -1.429 \\
Stat.t & $*$ & $* * *$ & $*$ & $* *$ & $*$ & - & $* *$ & $* * *$ & $*$ \\
Sig. & 0.917 & 1.565 & 1.775 & 1.352 & 1.689 & 1.720 & .943 & 1.593 & 1.717 \\
Durbin-watson & & & & & & & & & &
\end{tabular}

Notes: $\quad * * *, * *$, and $*$ denote significance at the 1 percent, 5 percent, and 10 percent levels, respectively (one-tailed test). AdjTAP is technical analysis performance after adjusted by buy and hold returns. MQUAL is market quality that is represented by the average of market capitalization of companies in a country. 
According to some robustness tests, results provided by this study are convincing. Therefore, the hypothesis is supported. It means that market quality negatively affects technical analysis performance.

\section{Discussion}

This study discusses the impact of stock market quality on technical analysis performance. Stock market quality is proxied by market capitalization for the biggest 50 companies in 21 countries.

Previous studies only compared technical analysis returns of each country like those of the U.S. (Bessembinder and Chan, 1995). Most Asian markets produce better returns than the US market's returns. They use the US market as a benchmark.

Milionis and Papanagiotou (2008) present the simulation that both Greece and US markets produce positive returns based on technical analysis indicators. After being adjusted by buy and hold returns, technical analysis still produces positive returns in the Greece market. Conversely, it generates negative returns in the US market.

Technical analysis generates bigger (lower) return in emerging (developed) stock markets. This study not only confirms previous studies, but also enriches the methods by using ratio scale in market quality and data coverage. Using global stock market data available from Yahoo Finance, this study provides evidence that market quality affects technical analysis performance.

In US, UK, France, Canada, Switzerland, Germany, Australia and Hong Kong, technical analysis signals do not produce profitable returns. Conversely, in Indonesia, $\mathrm{Ma}-$ laysia, Belgium, Israel, Austria, Argentina, New Zealand, and Greece, developing coun- tries, technical analysis produces more positive returns. It means that in developing countries, technical analysis signals are profitable.

This study not only uses different indicators (MA5, MA10, and MA15), but also different trading strategies (long, short, and long-short). Because of different market conditions in 2010 and 2011, this study also uses two-year technical analysis returns to provide a longer duration of technical analysis performance test. In 2011 (2010), short (long) strategies produce negative returns. In long or short strategies, $M A 5$ produce bigger returns than those for longer $M A 10$ and $M A 15$. These result confirm the study of Wong et al. (2002).

This study not only contributes to theoretical and methodological aspects of investment, but also gives insight to global investment managers about an alternative strategy, i.e. technical analysis, when they are creating their stock portfolios.

\section{Conclusion}

Based on the results and analysis presented above, here are some conclusions of this study. The proportion of market capitalization which represents the quality of stock market negatively affects technical analysis performance. These findings indirectly confirm the study by Fifield Fifield et al. (2005) in the European markets. The study by Bessembinder and Chan (1995) on Asian markets and Milionis and Papanagiotou (2008) on Greece and US markets also shows a similar phenomenon. This study contributes by using (1) some technical analysis indicators (MA5, MA10, and MA15), (2) some strategies (long, short, and long-short strategies), (3) more countries, and (4) the use of ratio scale of market quality as the determinant of technical analysis return. 
To expand this study, there are several developments that could be used. First, this study could be enriched with a broader sample of countries. Second, this study could be developed by using different indicators besides moving average (MA).

\section{Acknowledgement}

The authors gratefully acknowledge Faculty of Economics and Business at Universitas Gadjah Mada for supporting this study. The authors also appreciate the comments of research seminar participants at Universitas Gadjah Mada.

\section{References}

Ahmed, P., K. Beck, and E. Goldreyer. 2000 Can moving average technical trading strategies help in volatile and declining markets? A study of some emerging asian markets. Managerial Finance 26 (6): $49-62$.

Bessembinder, H., K. Chan. 1995. The profitability of trading rules in the Asian stock markets. Pasific-Basin Finance Journal 3: 257-284.

Brock, W., L. Lakonishok, and B. LeBaron. 1992. Simple technical trading rules and the stochastic properties of stock returns. Journal of Finance 47 (5): 1731-1764.

Fama, E. F., and M. E. 1966. Filter rules and stock-market trading. Journal of Business 39: 226-241.

Fifield, S. G. M., D. M. Power, and C. D. Sinclair. 2005. An analysis of trading strategies in eleven european stock markets. European Journal of Finance 11: 531-548.

Jensen, M. C., and W. H. 1976. Theory of the firm: Managerial behavior, agency costs and ownership structure. Journal of Financial Economics 3 (4): 305-360.

La Porta, R., F. Lopez-de-Silanes, A. Shleifer, and R. W. Vishny. 1998. Law and finance. Journal of Political Economy 106: 1113-1155.

La Porta, R., F. Lopez-de-Silanes, A. Shleifer, and R. W. Vishny. 2000a. Agency problems and dividend policies around the world. Journal of Finance 55: 1-33.

La Porta, R., F. Lopez-de-Silanes, A. Shleifer, and R. W. Vishny. 2000b. Investor protection and corporate governance. Journal of Financial Economics 58: 3-27.

La Porta, R., F. Lopez-de-Silanes, A. Shleifer, and R. W. Vishny. 2002. Investor protection and corporate valuation. Journal of Finance 57: 1147-1170.

Lara, J. M. G., B. G. Osma, and B. Gill-de-Albornoz. 2006. Effects of database choice on international accounting Research. Abacus 42 (3-4): 426-454.

Luca, C. 2000. Technical Analysis Applications in the Global Currency Markets (2 ${ }^{\text {nd }}$ ed.). Institute of Finance, New York.

McKenzie, M. D. 2007. Technical trading rules in emerging markets and the 1997 Asian currency crises. Emerging Markets Finance and Trade 43 (4): 46-73.

Milionis, A. E., and E. Papanagiotou. 2008. On the use of moving average trading rule test for weak form efficiency in capital markets. Review of Banking, Finance and Monetary Economics 2: 181-201. 
Shleifer, A., and R. W. Vishny. 1997. A survey of corporate governance. Journal of Finance 52 (2): 737-783. Sulistiawan, D., and J. Hartono. 2014. Can technical analysis signals detect price reaction around earnings announcement? Evidence from Indonesia. The International Journal of Business and Finance Research 8 (1): 113-123.

Sweeney R. J. 1988. Some new filter rule tests: Methods and results. Journal of Financial and Quantitative Analysis 2 (3): 285-300.

Wong, W., M. Manzur, and B. Chew. 2003. How rewarding is technical analysis? Evidence from Singapore Stock Market. Applied Financial Economics 13: 543-551. 
